\title{
MEASUREMENT OF PERFORMANCE MANAGEMENT USING BALANCED SCORECARD METHOD
}

\author{
Rina Anggi Lestari ${ }^{\bowtie}$, Achmad Slamet
}

Management Department, Faculty of Economics, Universitas Negeri Semarang, Semarang, Indonesia

\section{Info Article}

History Article:

Received August 2018

Approved September 2018

Published December 2018

Keywords:

Performance Measurement;

Balanced Scorecard; Health

Center.

\begin{abstract}
The aims of this research are to describe and analyze the level of performance management of RSUD Dr. Soeselo Kabupaten Tegal using the Balanced Scorecard method. Sampling was carried out by incidental sampling the sample size was determined using the formula solving and obtained 100 respondents. Data collection methods used are documentation and questionnaires. The analytical method used is descriptive quantitative analysis. The results obtained, in the 2015-2017 performance of the financial perspective was considered good. Customer perspective performance is considered good. The performance of learning and growth is considered good. The conclusions of this study are the overall performance of RSUD Dr. Soeselo Kabupaten Tegal is categorized quite well. The suggestion in observational it is advisable RSUD Dr. Soeselo Kabupaten Tegal needs to increase motivation and training for employees so that it can contribute to improving the performance of hospital services.
\end{abstract}

\section{Abstrak}

Penelitian ini bertujuan untuk mendeskripsikan dan menganalisis kinerja manajemen RSUD Dr. Soeselo Kabupaten Tegal dengan Metode Balanced Scorecard. Pengambilan sampel dilakukan dengan cara sampling incidental, ukuran sampel ditentukan dengan menggunakan rumus slovin dan diperoleh 100 responden pasien. Metode pengumpulan data yang digunakan adalah dokumentasi dan kuesioner. Metode analisis yang digunakan adalah analisis deskriptif kuantitatif. Hasil penelitian diperoleh, pada tahun 2015-2017 kinerja pada perspektif keuangan dinilai baik. Kinerja perspektif pelanggan dinilai baik. Kinerja perspektif proses bisnis internal dinilai baik. Kinerja perspektif pembelajaran dan pertumbuhan dinilai kurang baik. Simpulan dari penelitian ini yaitu secara keseluruhan kinerja RSUD Dr. Soeselo Kabupaten Tegal dikategorikan cukup baik. Saran yang dapat diberikan dalam penelitian ini adalah RSUD Dr. Soeselo Kabupaten Tegal perlu meningkatkan motivasi dan pelatihan pada karyawan, sehingga dapat memberikan kontribusi pada peningkatan kinerja pelayanan rumah sakit.

(C) 2018 Universitas Negeri Semarang 


\section{INTRODUCTION}

Performance is the degree to which a person's success in completing his work, which aims to provide feedback as an effort to increase the productivity of the company (Sudarma, 2012). Martono (2013) argues that the performance of a company can be seen from the level of the company in achieving goals based on the goals that have been set previously. Therefore, measurement of a company's performance is very important to do.

According to Nurcahya and Slamet (2015) with the performance measurement of the company will help the work unit manager in monitoring and improving the company's performance to achieve company goals. The right performance measurement system will improve the company's performance in managing all existing potential resources more efficiently, optimally and provide appropriate feedback for future performance improvements (Amelia, 2013).

Purbey et al. (2007) stated that good performance measurement system is a performance measurement system that shows characteristics such as performance measures from various perspectives and are interrelated, valid, reliable and easy to use. The measurement of the company's management performance generally still uses a traditional performance measurement system, where the measurement only emphasizes the financial aspects. Yanto and Muzammil (2016), companies that get high profits mean companies that have good performance. Trihastuti (2012) states that traditional performance management has weaknesses which are limited by time, expressing tangible financial performance without any hope that is seen from the factors that led to the achievement itself and inability to measure the performance of invisible assets (intangible assets) and intellectual property (human resources) of the company.

Kaplan and Norton (1992) the balanced scorecard complements a set of financial measures with operational measures on customer satisfaction, internal business processes and operational improvement activities that are drivers of future financial performance. Hartuti and Slamet (2017) stated that the balanced scorecard is a performance measurement tool that not only measures financial performance but also from a non-financial aspect that is complementary and has a casual relationship. According to Kollberg and Elg (2011) the balanced scorecard is a tool to make improvements and create knowledge at the operational level and leads to the openness of the company to increase management demands in making decent decisions based on measurable facts.

Regional General Hospital (RSUD) Dr. Soeselo Kabupaten Tegal is a Kabupaten Tegal Government hospital located in Jalan Dokter Soetomo No. 6 Slawi, Kabupaten Tegal. Measurement of the management performance of RSUD Dr. Soeselo Kabupaten Tegal uses traditional performance measurement, which only emphasizes financial aspects.

Based on the data obtained, during 20152017 the realization of the level of revenue achievement of RSUD Dr. Soeselo Kabupaten Tegal has not met the budget that has been set by the regional government. Hospital performance evaluation will be important to be carried out at this time because in determining the budget allocation policy as the participation of regional government capital in regional companies with economical, efficient and effective principles will be fulfilled if the performance of the company is considered good in accordance with the specified criteria. Judging from the number of hospital patient visits experienced an increase during 20152017. This shows the prospect of good performance because good customer performance can drive financial performance with an increase in income.

Performance measurement used by RSUD Dr. Soeselo Kabupaten Tegal is traditionally considered inappropriate. Wolok et al. (2018) performance measurement that uses financial aspects is a measurement used to measure the performance of business organizations, different from public sector organizations that are not looking for profit but service to the public. Therefore, public sector organizations can use the balanced scorecard in measuring their performance to determine the effectiveness and efficiency in providing services to the community (Handayani, 2011). Koumpouros (2013) in his research shows that the balanced scorecard can be proven to be very useful for effective management and policy-making and monitoring of public hospitals. In the research of Chen et al. (2006) shows that the balanced scorecard can reflect the characteristics of the health industry and identify opportunities in each problem for improvement.

Based on the above context, how is the performance of RSUD Dr. Soeselo Kabupaten Tegal when measured by the balanced scorecard method based on financial perspective, customer perspective, internal business process perspective and learning and growth perspective.

This study aims to analyze and describe: 1) RSUD Dr. Soeselo Kabupaten Tegal perfor- 


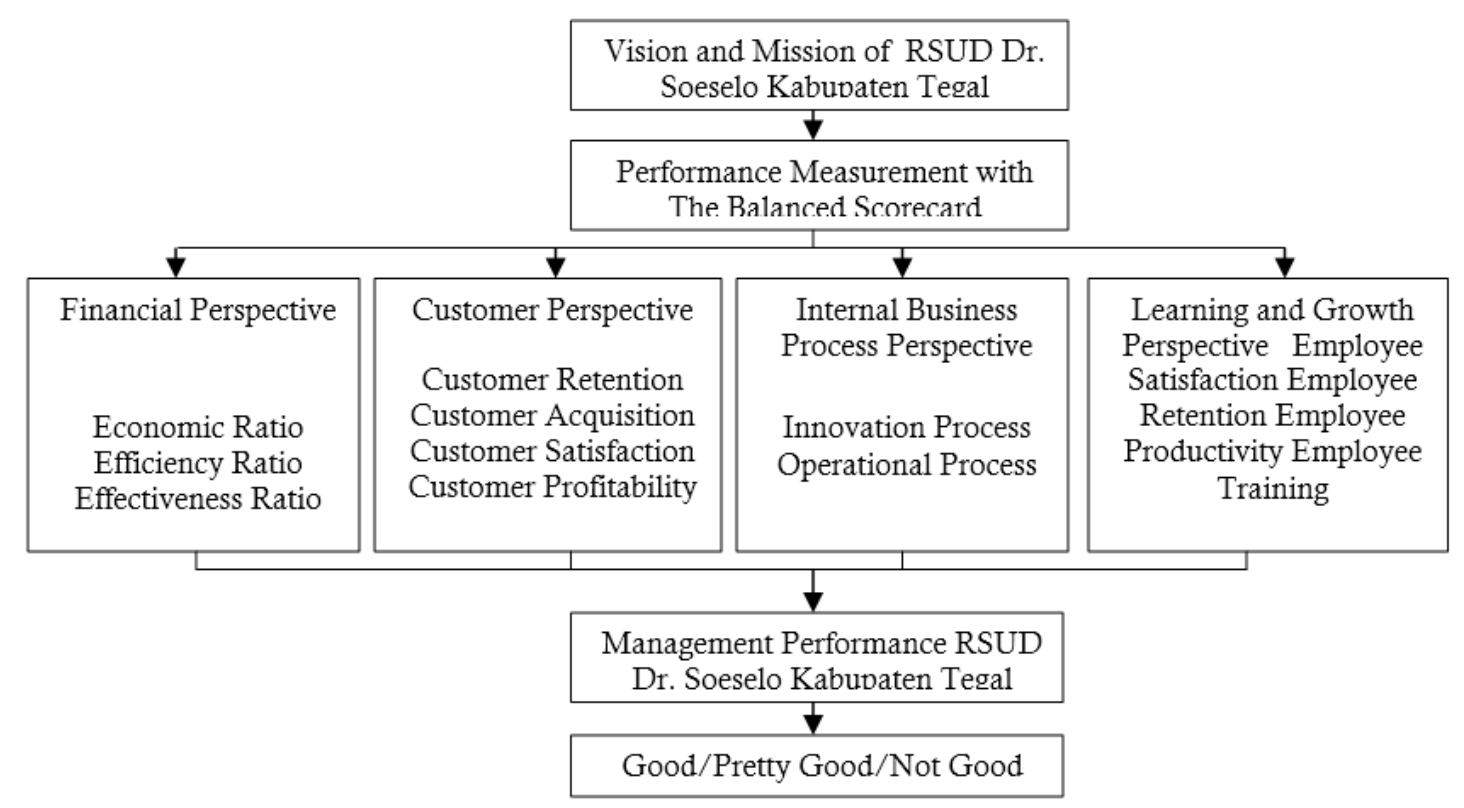

Figure 1. Research Model

mance is viewed from a financial perspective with the BSC method; 2) RSUD Dr. Soeselo Kabupaten Tegal performance is viewed from a customer perspective with the BSC method; 3) RSUD Dr. Soeselo Kabupaten Tegal performance is viewed from an internal business process perspective with the BSC method; 4) RSUD Dr. Soeselo Kabupaten Tegal performance is viewed from a learning and growth perspective with the BSC method.

This research is expected to produce concepts regarding the measurement of management performance with the balanced scorecard method which can be used as a reference for RSUD Dr. Soeselo Kabupaten Tegal to see whether the performance measurement has been done right or not and completes the existing assessment.

\section{Framework of Thinking}

RSUD Dr. Soeselo is a public sector organization engaged in health services. As a public sector organization, the main objective of the hospital is not only to seek profit but to provide quality services for the community. To achieve these objectives, it is necessary to measure performance that can measure the performance of a comprehensive hospital.

Performance measurement used by hospitals so far has not been able to describe the company's overall performance, because it only measures from a financial perspective. To overcome this weakness, the use of the balanced scorecard method as an alternative measure of company performance is the right thing. The balanced scorecard is a comprehensive performance measurement system, where performance measurement is carried out comprehensively based on four complementary perspectives.

The financial perspective measures the performance of a company based on economic methods, efficiency and effectiveness (value for money). Customer perspective measures company performance based on customer retention, customer acquisition, customer satisfaction and customer profitability. The internal business process perspective measures company performance based on the innovation process and the operating process. Learning and growth perspective measures company performance based on employee satisfaction, employee retention, employee productivity and employee training levels. The frame of mind in the study of management performance measurement with the balanced scorecard method in RSUD Dr. Soeselo Kabupaten Tegal can be seen in Figure 1.

\section{METHOD}

\section{Research Design}

Based on the characteristics of the problem and that research objectives to be achieved, this research is categorized into descriptive research with a quantitative approach. The descriptive research design is a research design arranged 
in order to provide a systematic description of scientific information derived from the subject or object of research (Sanusi, 2014). The quantitative approach according to Suparyogo (2001) is research that uses numerical data and analyzing using statistics.

\section{Object of Research}

The object of this research is RSUD Dr. Soeselo Kabupaten Tegal. This hospital is a hospital owned by the regional government. RSUD Dr. Soeselo Kabupaten Tegal has the vision to be the community's first choice hospital. While RSUD Dr. Soeselo Kabupaten Tegal has a mission is improving customer satisfaction, improving service performance according to hospital standards, increasing the capacity of human resources and providing superior services and implementing efficient and accountable financial performance.

\section{Population, Sample and Sampling Technique}

Population and sample in this study are used to support variable measurement techniques of patient satisfaction in the customer's perspective and employee satisfaction in the learning and growth perspective. While another perspective is measured by data analysis techniques according to secondary data that has been collected (nonsampling). The population is a generalization area which consists of an object/ subject that has certain qualities and characteristics set by researchers to be studied and then drawn conclusions (Suparyogo, 2017). The population in this study is the number of inpatient and outpatient visits in 2017 at RSUD Dr. Soeselo Kabupaten Tegal and the number of employee RSUD Dr. Soeselo Kabupaten Tegal in 2017.

The sampling technique for patient satisfaction in this study uses a non-random sampling method, namely incidental sampling technique, in this technique the determination is based on chance, i.e. anyone who happens to meet with a researcher can be used as a simple. In determining the number of samples using the Slovin formula. After calculating the Slovin formula, the number of respondents was 100 respondents. The sampling technique for employee satisfaction in this study is a simple random sampling technique. The sample in this study were 30 respondents of an employee at RSUD Dr. Soeselo Kabupaten Tegal.

\section{Research Variable}

This study uses indicators that are in the balanced scorecard concept. The first is the per- formance of a financial perspective that uses three value for money instruments developed by (Mahmudi, 2005). The instrument consists of economic ratio, efficiency ratio and effectiveness ratio.

Economic ratio describes the savings that include careful or careful management and no waste in use the budget. Based on Mahmudi (2005) the economic ratio can be calculated by the formula:

$$
\text { Economic Ratio }=\frac{\text { Institutional Expenditure }}{\text { The Budget Set by PEMDA }}
$$

Efficiency ratio describes the comparison between the number of costs used to earn income and the realization of income received. Based on Mahmudi (2005) the efficiency can be calculated by the formula:

Efficiency Ratio $=\frac{\text { Expenditure in Order to Earn Income }}{\text { Revenue Realization }}$

Effectiveness ratio measures the success or failure of the company in achieving its goals. Based on Mahmudi (2005) the effectiveness ratio can be calculated by the formula:

Effectiveness Ratio $=\frac{\text { Revenue Realization }}{\text { Revenue Targets Set by PEMDA }}$

The second indicator is the performance of the customer perspective as measured by customer retention, customer acquisition, customer satisfaction and customer profitability. Customer retention measures the extent of the company's success in retaining old customers. Based on Handayani (2011) customer retention can be calculated by the formula:

$$
\text { Customer Retention }=\frac{\text { Number of Old Patients }}{\text { Number of Patients }}
$$

Customer acquisition measures the extent to which the company successfully attracts new customers. Jumingan (2017) states that the greater the number of customer acquisition shows that the company's performance is getting better. Based on Handayani (2011) customer acquisition can be calculated by the formula:

Customer Acquisition $=\frac{\text { Number of New Patients }}{\text { Number of Patients }}$ 
The customer satisfaction measures the extent to which customers are satisfied with the organization's services. Customer satisfaction will be obtained by comparing the services expected by customers and services received by customers (Ayu \& Slamet, 2015). Permana (2013) states that customer satisfaction will be achieved if after the customer uses a product/ service, what the customer wants and needs can be fulfilled even exceeding this expectation. The level of customer satisfaction is measured by distributing questionnaires to customers/patients.

Customer profitability measures how companies are able to get customers who not only feel satisfied but also provide benefits. Based on Handayani (2011) customer profitability can be calculated by the formula:

$$
\text { Customer Profitability }=\frac{\text { Health Care Income }}{\text { Total Income }}
$$

The third indicator is the performance of the internal business process perspective as measured by the innovation process and the company's operating process. The innovation process is a stage where the company identifies the wants and needs of customers in the present and in the future and formulates ways to meet those needs (Kaplan \& Norton, 2000).

According to Asmoro and Maftukhah (2017), service innovations include service innovations related to service design and the development of news services. Based on Biyati (2013) the innovation process can be calculated by the formula:

$$
\text { Innovation Procces }=\frac{\text { New Services Offered }}{\text { Total Existing Services }}
$$

The operational process is measured by the level of outpatient visits and the rate of hospitalization visits. Based on Handayani (2011) the level of outpatient visits can be calculated by the formula:

Level of Outpatient $=\frac{\sum \text { Outpatient Visits }_{\mathrm{t}}-\sum \text { Outpatient Visits }_{\mathrm{h}-1}}{\sum \text { Outpatient Visits }_{\mathrm{h}-1}}$

The level of inpatient visits according to the Departemen Kesehatan RI in 2005 stated that there were several indicators of measuring hospital services to determine the level of effectiveness and efficiency, namely:

Bed Occupancy Rate (BOR) is the percentage of bed usage at a certain time unit.
Bed Occupancy Rate $=\frac{\text { Number of Days of Hospital Care }}{\text { Number of Bed } \times \text { Number of Days }}$

Bed Turn Over (BTO) is the frequency of use of a bed for a certain period, how many times the bed is used in a certain time unit.

Bed Turnover $=\frac{\text { Number of Patient Leaving (Alive and Dead) }}{\text { Number of Bed }}$

Turn Over Internal (TOI) is the average day that shows the bed not placed by the patient from being filled to the next filled time.

Turnover Internal $=\frac{(\text { Number of Bed } \times \text { Period })-\text { Treatment Day }}{\text { The Number of Patients Leaving }(\text { Alive and Dead })}$

Average Length of Stay (ALOS) is the average length of stay of a patient or the number of calendar days in which the patient receives hospitalization at the hospital.

Average Length of Stay $=\frac{\text { Amount of Patient Care }}{\text { The Number of Patients Leaving (Alive and Dead) }}$

Gross Death Rate (GDR) is the general mortality rate for every 1000 patients who are discharged.

Gross Death Rate $=\frac{\text { The Number of Patients Dies (Entirely) }}{\text { The Number of Patients Leaving (Alive and Dead) }}$

Net Death Rate (NDR) is a death rate of 48 hours after being treated for every 1000 patients out.

Net Death Rate $=\frac{\text { Number of Patients Dies }>48 \text { Hours }}{\text { The Number of Patients Leaving (Alive and Dead })}$

The fourth indicator is the performance of learning and growth perspective as measured by the level of employee satisfaction, employee retention, employee productivity and employee training. Employee satisfaction is a condition for increasing the productivity of quality responsiveness and customer service. Employee satisfaction in this study was measured by distributing questionnaires to an employee at RSUD Dr. Soeselo Kabupaten Tegal.

Jumingan (2015) states that the smaller employee retention, the better the company's performance. Based on Widhiyaningrat and Idayati (2016) employee retention can be calculated by the formula:

Employee Retention $=\frac{\text { Number of Employee Leaving }}{\text { Number of Employee }}$ 
Employee productivity is a measure of results, the overall impact of improving employee morale and expertise innovation, internal processes and customer satisfaction. Based on Handayani (2011) employee productivity can be calculated by the formula:

$$
\text { Employee Productivity }=\frac{\text { Services Revenue }}{\text { Number of Employee }}
$$

Yanto et al. (2017) stated that with socialization and training, employees could have more information about outside best practices to build performance within the company. Based on Widhiyaningrat and Idayati (2016) the level of employee training can be calculated by the formula:

$$
\text { Employee Training }=\frac{\text { Number of Employee Training }}{\text { Total Employee }}
$$

\section{Validity}

Validity is the degree of accuracy between the data that occurs in the object of research and data that can be reported by researchers (Suparyogo, 2017). Validity testing uses product moment correlation formula proposed by Pearson. The results of testing the patient satisfaction questionnaire and employee satisfaction $\mathrm{re}_{\text {count }}$ were then consulted with table with a significance level of 5 percent. From 19 statements for patients and 14 statements for employees submitted to 30 respondents obtained $r_{\text {count }}>0.361$ so that the research instrument can be said to be valid.

\section{Reliability}

Reliability is a test with regard to the degree of consistency and stability of data or findings (Suparyogo, 2017). The results of the calculation of reliability of patient satisfaction obtained Cronbach Alpha value of $0,938>0,70$ so that the research instrument can be said to be reliable and can be used as a research tool. While the results of the calculation of the reliability of employee satisfaction obtained Cronbach Alpha value of $0,954>0,70$ so that the research instrument can be said to be reliable and can be used as a research tool.

Documentation is the collection of secondary data from various sources, both personally and institutionally (Sanusi, 2014). The data needed includes reports on regional budget revenues and Netherlands, hospital financial reports, a recapitulation of hospital patient visits, a recapitulation of the number of hospital employees, a recapitulation of the number of employees parti- cipating in the training and hospital service standard performance data.

The questionnaire is a data collection technique that is done by giving a set of questions or written statements to the respondent to be answered (Suparyogo, 2017). In this study, a questionnaire was given to hospital patients to determine the level of patient satisfaction and the distribution of questionnaires to hospital employees to determine the level of satisfaction of hospital employees.

\section{Data Analysis Method}

This research is descriptive research that is research conducted by coming directly to the field to distribute questionnaires and documentation as well as other activities in an effort to obtain data, which is then processed, analyzed and described in the form of descriptive conclusions.

Steps of performance analysis of RSUD Dr. Soeselo Kabupaten Tegal district with the balanced scorecard methods start with the translation of RSUD Dr. Soeselo Kabupaten Tegal vision, mission and goals in four perspectives in the form of strategic objectives. After that determine the size of the results and the size of the trigger for performance. The next step is to measure the performance of each perspective in the balanced scorecard concept. After the measurement is done, then give a score of each performance indicator contained in the four balanced scorecard perspectives according to the standards that have been set each perspective. The final step is to make a scale to assess the total score so that the company's performance can be said to be "lacking," "enough," and "good."

\section{RESULTS AND DISCUSSION}

\section{Financial Perspective Performance}

Measuring the performance of the financial perspective using the value for money instrument developed by Mahmudi (2005) by referring to the revenue budget realization report and realization of expenditure budget of RSUD Dr. Soeselo Kabupaten Tegal. The economic ratio is a comparison of the realization of expenditure with the expenditure budget specified. The activity is said to be economical if the economic ratio value is $<100 \%$. The smaller the economic ratio value, the better the company's performance.

Table 1 shows a decline in economic ratio percentage of $1.88 \%$ in $2015-2016$, this indicates an increase in hospital performance in financial management. In 2016-2017 the economic ratio experienced an increase of $8.92 \%$. This increase 
Table 1. Economic Ratio

\begin{tabular}{cccc}
\hline Year & Expenditure Budget & Realization of Expenditure & Economic Ratio \\
\hline 2015 & IDR 192.560 .615 .000 & IDR 159.339 .129 .169 & $82.75 \%$ \\
2016 & IDR 192.900 .763 .000 & IDR 156.007 .813 .429 & $80.87 \%$ \\
2017 & IDR 147.216 .278 .000 & IDR 132.180 .717 .742 & $89.79 \%$ \\
\hline
\end{tabular}

Table 2. Efficiency Ratio

\begin{tabular}{cccc}
\hline Year & Expenses in Earning Income & Revenue Realization & Efficiency Ratio \\
\hline 2015 & IDR 159.339.129.169 & IDR 109.646.649.493 & $145.32 \%$ \\
2016 & IDR 156.007.813.429 & IDR 105.116.893.730 & $148.41 \%$ \\
2017 & IDR 132.180.717.742 & IDR 126.795.279.758 & $104.25 \%$ \\
\hline
\end{tabular}

Table 3. Effectiveness Ratio

\begin{tabular}{cccc}
\hline Year & Revenue Target & Revenue Realization & Effectiveness Ratio \\
\hline 2015 & IDR 100.000 .000 .000 & IDR 109.646.649.493 & $109.65 \%$ \\
2016 & IDR 112.000 .000 .000 & IDR 105.116.893.730 & $93.85 \%$ \\
2017 & IDR 125.623 .138 .901 & IDR 126.795 .279 .758 & $100.93 \%$ \\
\hline
\end{tabular}

shows the performance of the hospital has decreased performance. However, the economic ratio value from 2015 to 2017 is still in the range of $<100 \%$ meaning that the performance of the hospital is said to be economical.

The efficiency ratio is a comparison between expenditure in order to get income with the realization of income. Company performance is said to be efficient if the efficiency ratio is < $100 \%$. The smaller the value of the efficiency ratio, the better the company's performance.

Based on Table 2. shows that in 2015-2016 there was an increase in the efficiency ratio of $3.09 \%$, this indicates that the hospital's performance has decreased. However, in 2016-2017 the efficiency ratio decreased by $44.16 \%$ which indicated that there was an increase in hospital performance. Despite fluctuations in efficiency ratio but still above $100 \%$, it means that the performance of hospital is categorized as inefficient.

The effectiveness ratio comparison between the realization of revenue and a predetermined income budget. Company performance is said to be effective if the effectiveness ratio is $>$ $100 \%$. The higher the value of the effectiveness ratio, the better the company's performance.

Table 3 shows a decrease in the effectiveness ratio of $15.8 \%$ in $2015-2016$. This indicates that hospital performance has decreased. In 2016-2017 the ratio of effectiveness increased by $7.08 \%$ meaning that there was an increase in hos- pital performance. Overall, hospital performance in 2015 and 2017 were categorized as effective because the effectiveness ratio $>100 \%$. Whereas in 2016 the value of the effectiveness ratio $<100 \%$ means that the performance of the hospital is categorized as ineffective.

Performance RSUD Dr. Soeselo Kabupaten Tegal based on a financial perspective which is measured using value for money research instruments which include economic ratio, efficiency ratio and effectiveness ratio indicating that the amount of expenditure does not exceed the expenditure budget that has been set so that it is said to be economical. The amount of income does not exceed expenditure in obtaining income si it is said to be efficient. The amount of income exceeds the predetermined income budget, so that is said to be effective. Therefore, it can be concluded that the performance of the financial perspective is categorized as good.

\section{Customer Perspective Performance}

Performance measurement of customer perspective is done by using four indicators, namely customer retention, customer acquisition, customer satisfaction and customer profitability.

Customer retention is the level of the company's ability to maintain patients. The greater the level of customer retention indicates the better performance of the hospital in maintaining a relationship with patients. 
Table 4. Customer Retention

\begin{tabular}{cccc}
\hline Year & $\begin{array}{c}\text { Old } \\
\text { Patient }\end{array}$ & $\begin{array}{c}\text { Total } \\
\text { Patient }\end{array}$ & $\begin{array}{c}\text { Customer } \\
\text { Retention }\end{array}$ \\
\hline 2015 & 76,767 & 172,977 & $44.38 \%$ \\
2016 & 78,151 & 173,277 & $45.10 \%$ \\
2017 & 87,903 & 183,975 & $47.78 \%$ \\
\hline
\end{tabular}

Table 4 shows an increase in customer retention rates from 2015 to 2017. In 2015-2016 customer retention increased by $0.72 \%$. In 2016 2017 customer retention increased by $2.68 \%$. This shows that the hospital's performance has been categorized as good because it is able to maintain a good relationship with patients, so as to create patient trust and loyalty to the hospital.

Customer acquisition shows how much the hospital is able to attract new patients. Jumingan (2017) states that the greater the customer acquisition rate shows that the hospital's performance is getting better.

Table 5. Customer Acquisition

\begin{tabular}{cccc}
\hline Year & $\begin{array}{c}\text { New } \\
\text { Patient }\end{array}$ & $\begin{array}{c}\text { Total } \\
\text { Patient }\end{array}$ & $\begin{array}{c}\text { Customer } \\
\text { Acquisition }\end{array}$ \\
\hline 2015 & 68,683 & 172,977 & $39.71 \%$ \\
2016 & 67,830 & 173,277 & $39.15 \%$ \\
2017 & 66,145 & 183,975 & $35.95 \%$ \\
\hline
\end{tabular}

Based on Table 5 shows the level of customer acquisition RSUD Dr. Soeselo Kabupaten Tegal experienced a decline from 2015 to 2017. The level of customer acquisition decreased by $0.56 \%$ in $2015-2016$ and by $3.2 \%$ in $2016-2017$. This shows that the performance of RSUD Dr. Soeselo Kabupaten Tegal has declined and is categorized as not good.

Patient satisfaction shows how much satisfaction the patient has for the services provided by the hospital. The measurement of patient satisfaction was carried out using a questionnaire consisting of nineteen statements covering five attributes in determining the quality of services, namely: tangibles, reliability, responsiveness, empathy and assurance. The questionnaire used by the researcher is a questionnaire developed from the questionnaire used by Juwita et al. (2017) in his research. Of the 100-questionnaire consisting of nineteen question items, the overall value of the question was included in the calculation. From these data can determine the level of customer satisfaction.

$\mathrm{IK} \max =5 \times 19 \times 100=9,500$

$\mathrm{IK} \min =1 \times 19 \times 100=1,900$

Interval $=(9,500-1,900) / 5=1,520$

From this interval the customer satisfaction index is:

Tabel 6. Customer Satisfaction Index

\begin{tabular}{cc}
\hline Score Interval & Level of Satisfaction \\
\hline $7981-9500$ & Very Satisfied \\
$6461-7980$ & Satisfied \\
$4941-6460$ & Quite Satisfied \\
$3421-4940$ & Not Satisfied \\
$1900-3420$ & Very Dissatisfied \\
\hline
\end{tabular}

The calculation of the total score from the results of the questionnaire is 7,582. Based on the above categories, the results achieved are in the range of $6,461-(7,582)-7,980$ with satisfied interpretation. This illustrates the RSUD Dr. Soeselo Kabupaten Tegal patients were satisfied with the performance and services provided by RSUD Dr. Soeselo Kabupaten Tegal.

Customer Profitability is measured by comparing the amount of health service income with total income.

Table 7 shows an increase in customer profitability from 2015 to 2017. In 2015-2016, customer profitability increased by $6.26 \%$. Whereas in 2016-2017, customer profitability increased by $24.81 \%$. This shows that the performance of hospital seen from the probability of customers is considered good.

Performance RSUD Dr. Soeselo Kabupaten Tegal based on customer perspective measured using customer retention, customer acquisition, customer satisfaction and customer profitability categorized as good.

Table 7. Customer Profitability

\begin{tabular}{cccc}
\hline Year & Health Care Income & Total Income & Customer Profitability \\
\hline 2015 & IDR 105.731.098.111 & IDR 160.807.646.835 & $65.75 \%$ \\
2016 & IDR 107.531.113.875 & IDR 149.336.367.435 & $72.01 \%$ \\
2017 & IDR 122.900.180.703 & IDR 126.936.143.815 & $96.82 \%$ \\
\hline
\end{tabular}




\section{Internal Business Process Performance}

The internal business process perspective consists of the innovation process and the operating process. In the operation process, there are two indicates used, namely the level of outpatient visits and the level of hospitalization visits. The measurement used for inpatient visit rates use indicators set by Departemen Kesehatan RI in 2005.

The innovation Process is used to find out the number of new services offered by the hospital compared to the number of services already available (Biyati, 2013). Types of services that already exist in RSUD Dr. Soeselo Kabupaten Tegal includes: Emergency Room Installation Services, Outpatient, Inpatient Installation, Laboratory, Radiology, Central Surgical Installation, Intensive Care Unit, Medical Rehabilitation, Hemodialysis, Hospital Blood Bank, Pharmacy Installation, Obstetric Emergency Services and Heart Services.

Whereas new service innovations conducted by RSUD Dr. Soeselo Kabupaten Tegal includes: Griya Jamu Adas Pulowaras, Medical Acupuncture Services, Playground Facilities in The Child Care Room, Outpatient Online Registration System Services and Registration System Services Via SMS. The equation used to find the level of innovation is as follows:

$$
\text { Innovation }=(5 / 18) \times 100 \%=27.78 \%
$$

Based on the performance appraisal criteria, the method of calculating the innovation process performance measurement is $27.78 \%$, so it is categorized quite good. The level of outpatient visits is intended to determine the use of the hospital and some workload that must be borne by RSUD Dr. Soeselo Kabupaten Tegal.

Table 8. Outpatient Visit Level

\begin{tabular}{ccc}
\hline Year & $\begin{array}{c}\text { Number of Out- } \\
\text { patient Visits }\end{array}$ & $\begin{array}{c}\text { Percentage In- } \\
\text { crease/ Decrease }\end{array}$ \\
\hline 2014 & 75,313 & - \\
2015 & 114,993 & Increase $52.69 \%$ \\
2016 & 116,430 & Increase $1.25 \%$ \\
2017 & 124,878 & Increase $7.26 \%$ \\
\hline
\end{tabular}

Based on Table 8 shows that from year to year the average level of outpatient visits of RSUD Dr. Soeselo Kabupaten Tegal has always experienced an increase. This shows that the hospital is able to foster good communication through check-up so that the level of inpatient visits is categorized as good. The level of hospi- talization visits is used to determine the level of inpatient visits by using hospital performance indicators that indicate the quality of hospital services.

Bed Occupancy Ratio (BOR) is the percentage of bed usage at a certain time unit. The ideal BOR value is $60 \%-85 \%$.

Table 9. Bed Occupancy Ratio (BOR)

\begin{tabular}{cccc}
\hline Year & $\begin{array}{c}\text { Bed Occupan- } \\
\text { cy Rate (BOR) }\end{array}$ & Average & Standard \\
\hline 2015 & $81.20 \%$ & & \\
2016 & $80.25 \%$ & $80.99 \%$ & $60 \%-85 \%$ \\
2017 & $81.53 \%$ & & \\
\hline
\end{tabular}

Based on Table 9 shows that the average value of BOR RSUD Dr. Soeselo Kabupaten Tegal of $80.99 \%$ is an ideal number because it is still in the ideal standard range of BOR values set by Departemen Kesehatan RI in 2005, which $60-85 \%$

Average Length of Stay (ALOS) is a ratio that measures the average period or period of a patient being treated or using a hospital service. The ideal service period is 3-6 days.

Table 10. Average Length of Stay (ALOS)

\begin{tabular}{cccc}
\hline Year & $\begin{array}{c}\text { Average } \\
\text { Length of } \\
\text { Stay (ALOS) }\end{array}$ & Average & Standard \\
\hline 2015 & 3.85 days & 4.22 & $3-6$ \\
2016 & 4.21 days & days & days \\
2017 & 4.61 days & & \\
\hline
\end{tabular}

Based on Table 10 shows that the average value of the ALOS of RSUD Dr. Soeselo Kabupaten Tegal for 4.22 days is an ideal number because it is still the ideal standard range of ALOS values set by Departemen Kesehatan RI in 2005 , which is 3-6 days.

Bed Turn Over (BTO) is the frequency of use of a bed, how many times a unit of time is a hospital bed used by the patient. BTO's ideal value is $30-40$ times.

Table 11. Bed Turn Over (BTO)

\begin{tabular}{cccc}
\hline Year & $\begin{array}{c}\text { Bed Turn } \\
\text { Over (BTO) }\end{array}$ & Average & Standard \\
\hline 2015 & 76.89 time & 72.71 & $30-40$ \\
2016 & 69.81 time & time & time \\
2017 & 71.42 time & & \\
\hline
\end{tabular}


Based on Table 11 shows that the average value of the BTO of RSUD Dr. Soeselo Kabupaten Tegal at 72.71 times is the ideal number because it is still the ideal standard range of BTO values set by Departemen Kesehatan RI in 2005, which is 30-40 times.

Turn Over Interval (TOI) is the level of efficiency of the use of a bed. The standard number of empty beds is only 1-3 days.

Table 12. Turn Over Interval (TOI)

\begin{tabular}{cccc}
\hline Year & $\begin{array}{c}\text { Turn Over } \\
\text { Interval (TOI) }\end{array}$ & Average & $\begin{array}{c}\text { Stan- } \\
\text { dard }\end{array}$ \\
\hline 2015 & .89 days & & \\
2016 & 1.04 days & .96 days & $1-3$ days \\
2017 & .94 days & & \\
\hline
\end{tabular}

Based on Table 12 shows that the average value of TOI RSUD Dr. Soeselo Kabupaten Tegal for 0,96 days is an ideal number, because it is still in the ideal standard range of the TOI value set by Departemen Kesehatan RI in 2005, which 1-3 days.

Gross Death Rate (GDR) is the total number of deaths that occur in a hospital, both those treated for less than 48 hours for those treated for more than 48 hours. The ideal value of GDR is less than $45 \%$.

Table 13. Gross Death Rate (GDR)

\begin{tabular}{cccc}
\hline Year & $\begin{array}{c}\text { Gross Death } \\
\text { Rate (GDR) }\end{array}$ & Average & Standard \\
\hline 2015 & $4.07 \%$ & & \\
2016 & $3.66 \%$ & $3.74 \%$ & $<45 \%$ \\
2017 & $3.48 \%$ & & \\
\hline
\end{tabular}

Based on Table 13 shows that the average GDR value of RSUD Dr. Soeselo Kabupaten Tegal, amounting to $3.74 \%$ is an ideal number, because it is still in the ideal standard range of the GDR value set by Departemen Kesehatan RI in 2005 , which is $<45 \%$.

Nett Death Rate (NDR) is the ratio of patients to die $>48$ hours, or after two days of treatment, every 1000 patients leave. The ideal NDR value is less than $25 \%$.

Table 14. Nett Death Rate (NDR)

\begin{tabular}{cccc}
\hline Year & $\begin{array}{c}\text { Nett Death } \\
\text { Rate (NDR) }\end{array}$ & Average & Standard \\
\hline 2015 & $3.14 \%$ & & \\
2016 & $2.65 \%$ & $2.81 \%$ & $<25 \%$ \\
2017 & $2.64 \%$ & & \\
\hline
\end{tabular}

Based on Table 14 shows that the average NDR value of RSUD Dr. Soeselo Kabupaten Tegal at $2.81 \%$ is an ideal number because it is still the ideal standard range of NDR values set by Departemen Kesehatan RI in 2005, which < $25 \%$.

Performance RSUD Dr. Soeselo Kabupaten Tegal based on the internal business process perspective that is measured using the innovation process and the operation process is categorized as good.

\section{Learning and Growth Perspective Perfor-} mance

Performance measurement of the learning and growth perspective at RSUD Dr. Soeselo Kabupaten Tegal uses indicators namely employee satisfaction, employee retention, employee productivity and employee training level.

Employee satisfaction is measured by distributing questionnaires to hospital employees as many as 30 respondents consisting of 14 statements which include, recognition of work performance, involvement in decision making, access to information, encouragement to do creativity and initiative and support from superiors.

From these data can be determined the satisfaction interval to then be used to determine the level of customer satisfaction.

IK $\max =5 \times 14 \times 30=2,100$
IK $\min =1 \times 14 \times 30=420$
Interval $=(2,100-420) / 5=336$

From this interval the customer satisfaction index is:

Table 15. Employee Satisfaction Index

\begin{tabular}{cc}
\hline Score Interval & Level of Satisfaction \\
\hline $1765-2100$ & Very Satisfied \\
$1429-1764$ & Satisfied \\
$1093-1428$ & Quite Satisfied \\
$757-1092$ & Not Satisfied \\
$420-756$ & Very Dissatisfied \\
\hline
\end{tabular}

Calculating the total score from the results of the questionnaire is 1434. Based on the above categories, the results achieved were in the range of $1429-(1434)-1764$ with a satisfied interpretation. This illustrates that employee RSUD Dr. Soeselo Kabupaten Tegal was satisfied with the policies in the hospital about the work they did.

Employee retention is used to measure the ability of hospitals to maintain good relations 
with employees. The measurement of employee retention is the comparison between the number of employees who come out with the total number of hospital employees.

Table 16. Employee Retention

\begin{tabular}{cccc}
\hline Year & $\begin{array}{c}\text { Employee } \\
\text { Comes } \\
\text { Out }\end{array}$ & $\begin{array}{c}\text { Number of } \\
\text { Employees }\end{array}$ & $\begin{array}{c}\text { Employee } \\
\text { Retention }\end{array}$ \\
\hline 2015 & 10 & 672 & $1,49 \%$ \\
2016 & 14 & 715 & $1,96 \%$ \\
2017 & 17 & 787 & $2,16 \%$ \\
\hline
\end{tabular}

Based on Table 16 shows that employee retention has increased by $0.47 \%$ in $2015-2016$. In 2016-2017 employee retention increased by $0.2 \%$. This shows that the performance of RSUD Dr. Soeselo Kabupaten Tegal was seen from the decline in employee retention and categorized as not good.

Employee productivity is a measure of results, the overall impact of efforts to increase employee morale and expertise, innovation, internal processes and customer satisfaction. Employee productivity is measured by comparing service revenues with the number of employees in the current year.

Based on Table 17 shows a decrease in employee productivity from 2015 to 2017 . In 2015-2016, employee productivity decreased by 30.435 .042 . Whereas in 2016-2017, employee productivity decreased by 47.570 .891 . This shows that the performance of RSUD Dr. Soeselo Kabupaten Tegal seen from the productivity of employees is considered not good.

Employee training is carried out in the hope that the capability of hospital employees will increase. Thus, the hospital will maintain the existence of these employees, so they do not leave the hospital. The ratio of employee training can be used to assess the commitment of RSUD Dr. Soeselo Kabupaten Tegal in improving the knowledge, intelligence and skills of his employees in order to support the implementation of tasks.
Table 18. Employee Training

\begin{tabular}{cccc}
\hline Year & $\begin{array}{c}\text { Number of } \\
\text { Employees } \\
\text { Training }\end{array}$ & $\begin{array}{c}\text { Number } \\
\text { of Em- } \\
\text { ployees }\end{array}$ & $\begin{array}{c}\text { Employee } \\
\text { Training }\end{array}$ \\
\hline 2015 & 113 & 672 & $16.82 \%$ \\
2016 & 668 & 715 & $93.43 \%$ \\
2017 & 412 & 787 & $52.35 \%$ \\
\hline
\end{tabular}

Based on Table 18 shows that the number of RSUD Dr. Soeselo Kabupaten Tegal employees who attended the training experienced fluctuations every year. According to Lestari (2016), the level of employee training is considered good if experiences an increase, judged to be moderate when fluctuating and judge to be less if it has decreased. So that in 2015, 2016 and 2017 the level of employee training was categorized quite good.

Performance RSUD Dr. Soeselo Kabupaten Tegal based on learning and growth perspective is categorized as not good. This is because the hospital has not been able to retain its employees so that the number of employees coming out continues to increase. In addition, the productivity of hospital employees is also categorized as not good because the amount of service income obtained by hospital always decreases during 20152017.

Overall performance measurement results from RSUD Dr. Soeselo Kabupaten Tegal shows that the performance of hospital management in 2015, 2016 and 2017 is categorized quite good. This means that the management performance of RSUD Dr. Soeselo Kabupaten Tegal is quite good when measured by the balanced scorecard method.

\section{CONCLUSION AND RECOMMENDATION}

Based on the results of research and discussion on the research, it can be concluded that the management performance of RSUD Dr. Soeselo Kabupaten Tegal is based on a financial perspective which is measured using a value for money research instrument which includes economic ratio, efficiency ratio and effectiveness

Table 17. Employee Productivity

\begin{tabular}{cccc}
\hline Year & Services Revenue & Number of Employees & Employee Productivity \\
\hline 2015 & 160.807 .646 .835 & 672 & 239.297 .094 \\
2016 & 149.336 .367 .435 & 715 & 208.862 .052 \\
2017 & 126.936 .143 .815 & 787 & 161.291 .161 \\
\hline
\end{tabular}


ratio indicating that management performance is categorized as good. Although the efficiency ratio is categorized as ineffective in 2016 and the efficiency ratio is categorized as inefficient.

Management performance of RSUD Dr. Soeselo Kabupaten Tegal based on customer perspective measured using customer satisfaction, customer retention, customer acquisition and customer profitability shows that management performance is categorized as good. Customer retention is considered good because the hospital is able to maintain the number of patients achieved every year. Acquisition of customer is considered not good because of the performance of the hospital to attract new patients to seek treatment at RSUD Dr. Soeselo Kabupaten Tegal has decreased every year. At the level of patient satisfaction is considered good because based on the results of the questionnaire, hospital patients are satisfied with the performance and services provided by the hospital. While customer profitability is considered good because the income earned on health services is always increasing.

Management performance RSUD Dr. Soeselo Kabupaten Tegal based on internal business process perspective as measured by the innovation process and the operation process is categorized as good. This is evidenced by the new service innovations carried out by the hospital and the increasing number of outpatients. In addition, it is seen from the quality of hospital services which is indicated by the average number of ratios that show the quality of hospital services in accordance with ideal standards. However, it's just that the Bed Turn Over (BTO) value of the hospital is still outside the ideal range that describes the realization of beds that are not guaranteed due to high demand.

Management performance RSUD Dr. Soeselo Kabupaten Tegal based on learning and growth perspective is categorized as not good. At the level of employee satisfaction is considered good because based on the survey employees feel satisfied with the hospital's policy in work performed. At the level of employee retention, it is considered not good enough, meaning that the hospital has not been able to retain its employees so that the number of employees leaving and the number of employee turnover is increasing. Employee productivity is considered not good because the service income earned by the hospital always decreases. While the level of employee training is considered to be quite good, meaning that it is almost entirely in the hospital to include its employees to be involved in the existing training.
Based on the research that has been carried out, the author gives advice to the management of RSUD Dr. Soeselo Kabupaten Tegal it is recommended to improve performance on learning and growth perspectives. The hospital needs to provide motivation, knowledge and training to employees so that they can provide encouragement to work better so that they can increase employee loyalty which will be followed by performance services that satisfy patients. This will contribute to improving patient satisfaction so that it will encourage patients to return to hospital services and attract new patients. Thus, the hospital can also increase the amount of revenue so that it reaches the predetermined revenue target. For academics who want to do research using the balanced scorecard method, it is advisable to be able to research several objects so that they can compare the performance between one institution and another.

\section{REFERENCES}

Amelia, L. (2013). Perancangan Sistem Pengukuran Kinerja di Fakultas Teknik Universitas Esa Unggul Menggunakan Metode Balanced Scorecard dan AHP. Jurnal Inovisi, 9(1), 1-17.

Asmoro, D. R., \& Maftukhah, I. (2017). Pengaruh Kualitas Layanan, Citra Merk dan Inovasi Layanan terhadap Kepuasan Pasien Rawat Inap pada RS Keluarga Sehat di Kabupaten Pati. Management Analysis Journal, 6(1), 76-82.

Ayu, M., \& Slamet, A. (2015). Analisis Kepuasan Pelanggan Mengenai Kualitas Pelayanan Astra Motor Slawi di Kabupaten Tegal. Management Analysis Journal, 4(4), 318-325.

Biyati, I. (2013). Analisis Pengukuran Kinerja Rumah Sakit Umum Daerah Rokan Hulu dengan Pendekatan Balanced Scorecard. Doctoral Dissertation. Universitas Islam Negeri Sultan Syarif Kasim Riau Pekanbaru.

Chen, X. Y., Yamauchi, K., Kato, K., Nishimura, A., \& Ito, K. (2006). Using the Balanced Scorecard to Measure Chinese and Japanese Hospital Performance. International Journal of Health Care Quality Assurance, 19(4), 339-350.

Departemen Kesehatan RI. (2005). Standar Minimal Pelayanan Rumah Sakit. Jakarta: Dirjen Binkesmas.

Handayani, B. D. (2011). Pengukuran Kinerja Organisasi dengan Pendekatan Balanced Scorecard pada RSUD Kabupaten Kebumen. Jurnal Dinamika Manajemen, 2(1), 78-91.

Hartuti, E. M., \& Slamet, A. (2017). Analisis Kinerja Manajemen Rumah Sakit Umum Bina Kasih Ambarawa dengan Pendekatan Balanced Scorecard. Management Analysis Journal, 6(4), 398-409.

Jumingan, J. (2017). Analisis Kinerja Manajemen Berdasarkan Balanced Scorecard. Jurnal Bisnis dan Manajemen, 15(1), 45-56 
Juwita, G. S., Marlinae, L., \& Rahman, F. (2017). Hubungan Mutu Pelayanan dengan Kepuasan Pasien Rawat Inap di Rumah Sakit Umum Daerah Tamiang Layang. Jurnal Publikasi Kesehatan Masyarakat Indonesia, 4(2), 49-56.

Kaplan, R. S., \& Norton, D. P. (1992). The Balanced Scorecard-Measures that Drive Performance. Harvard Business Review, 70(1), 75-86.

Kaplan, R. S., \& Norton, D. P. (2000). Balanced Scorecard: Menerapkan Strategi Menjadi Aksi. Jakarta: Erlangga.

Kollberg, B., \& Elg, M. (2011). The Practice of the Balanced Scorecard in Health Care Service. International Journal of Productivity and Performance Management, 60(5), 427-445.

Koumpouros, Y. (2013). Balanced Scorecard: Application in the General Panarcadian Hospital of Tripolis Greece. International Journal of Health Care Quality Assurance, 26(4), 286-307.

Lestari, S. (2016). Pengukuran Kinerja dengan Pendekatan Balanced Scorecard pada Rumah Sakit PKU Muhammadiyah Gombong Tahun 2013 dan 2014. Skripsi. Yogyakarta: Universitas Negeri Yogyakarta.

Mahmudi, M. (2005). Manajemen Kinerja Sektor Publik. Akademi Manajemen Perusahaan YKPN, Yogyakarta.

Martono, S. (2013). Strategi Peningkatan Kinerja Program Studi melalui Optimalisasi Peran Pemimpin. Jurnal Dinamika Manajemen, 4(1), 3045.

Nurcahya, A. H., \& Slamet, A. (2015). Analisis Kinerja Perusahaan Daerah Air Minum dengan Metode Balanced Scorecard. Management Analysis Journal, 4(1), 1-15.

Permana, M. V. (2013). Peningkatan Kepuasan Pelang- gan melalui Kualitas Produk dan Kualitas Layanan. Jurnal Dinamika Manajemen, 4(2), 115-131.

Purbey, S., Mukherjee, K., \& Bhar, C. (2007). Performance Measurement System for Healthcare Processes. International Journal of Productivity and Performance Management, 56(3), 241-251.

Sanusi, A. (2014). Metodologi Penelitian Bisnis. Jakarta: Salemba Empat.

Sudarma, K. (2012). Mencapai Sumber Daya Manusia Unggul (Analisis Kinerja dan Kualitas Pelayanan). Jurnal Dinamika Manajemen, 3(1), 76-83.

Suparyogo, I. (2001). Metode Penelitian Kuantitatif, Kualitatif, dan $R \& D$. Bandung: CV. Alfabeta.

Trihastuti, K. (2012). Analisis Kinerja Perusahaan dengan Metode BSC. Management Analysis Journal, 1(1), 1-9.

Widhiyaningrat, W. A., \& Idayati, F. (2016). Pengukuran Kinerja Organisasi Nirlaba dari Perspektif Balanced Scorecard pada Rumah Sakit Umum Haji Surabaya. Jurnal Ilmu \& Riset Akuntansi, 4(6), 1-20.

Wolok, E., Siregar, H., Djohar, S., \& Baga, L. M. (2018). Performance Analysis of Transform University Studies in Indonesia Context. Jurnal Dinamika Manajemen, 9(1), 44-55.

Yanto, H., \& Muzzammil, B. S. (2016). A Long Way to Implement Environmental Reporting in Indonesian Mining Companies. IJABER, 14(10), 6493-6514.

Yanto, H., Yulianto, A., Sebayang, L. K. B., \& Mulyaga, F. (2017). Improving the Compliance with Accounting Standards without Public Accountability (SAKETAP) by Developing Organizational Culture: a Case of Indonesian SMEs. The Journal of Applied Business Research, 33(5), 929940. 